\title{
Fluoride Release from Restorative Materials
}

\author{
Gabriela Romanini BASSO${ }^{1}$ \\ Álvaro DELLA BONA² \\ Delton Luiz GOBBI ${ }^{3}$ \\ Dileta CECCHETTI ${ }^{4}$
}

\author{
${ }^{1}$ Dental School, UFSC - Federal University of Santa Catarina, Florianópolis, SC, Brazil \\ ${ }^{2}$ Graduate Program in Clinical Dentistry, Dental School, UPF - University of Passo Fundo, Passo Fundo, RS, Brazil \\ ${ }^{3}$ Department of Chemistry, UPF - University of Passo Fundo, Passo Fundo, RS, Brazil \\ ${ }^{4}$ Department of Statistics, Federal Agricultural College of Sertão, Sertão, RS, Brazil
}

\begin{abstract}
The aim of this study was to evaluate in vitro fluoride (F) release from 4 restorative materials (3M ESPE): Ketak Molar Easymix [KME - conventional glass ionomer cement (GIC)]; Rely-X luting 2 [RL2 - resin-modified GIC (RMGIC)]; Vitremer (VIT- RMGIC); and Filtek Z250 [Z250 - negative control]. Disc-shaped specimens were fabricated according to the manufacturer's instructions and placed into $10 \mathrm{~mL}$ of reverse osmosis water at $37^{\circ} \mathrm{C}$ until the analyses were done using a liquid membrane for selective $\mathrm{F}$ ion electrode (Orion 710). F release was evaluated every $6 \mathrm{~h}$ in the first day and thereafter daily during 28 days (d). The results were analyzed statistically by two-way ANOVA and Tukey's test $(\alpha=0.05)$. Mean F release and standard deviation values (in ppm) were: KME: $6 \mathrm{~h}-0.34 \pm 0.04$; 24 h- $1.22 \pm 0.30 ; 7$ d- $0.29 \pm 0.09 ; 14$ d- $0.20 \pm 0.04 ; 28$ d- $0.16 \pm 0.01 ;$ RL $2: 6$ h- $2.46 \pm 0.48 ; 24$ h-12.33 $\pm 2.93 ; 7$ d- $1.37 \pm 0.38$; 14 d- $0.80 \pm 0.13 ; 28$ d- $0.80 \pm 0.21$; VIT: 6 h- $0.98 \pm 0.35 ; 24$ h- $4.35 \pm 1.22 ; 7$ d- $0.66 \pm 0.23 ; 14$ d- $0.40 \pm 0.07 ; 28$ d- $0.39 \pm 0.08$; Z250: 6 h- $0.029 \pm 0.001 ; 24$ h- $0.024 \pm 0.009 ; 7$ d- $0.023 \pm 0.004 ; 14$ d- $0.025 \pm 0.001 ; 28$ d- $0.028 \pm 0.001$. RL2 RMGIC released more $\mathrm{F}$ than the other materials in all periods. The greatest release of $\mathrm{F}$ occurred in the first $24 \mathrm{~h}$.
\end{abstract}

Key Words: Fluoride, glass ionomer cement, dental materials.

\section{INTRODUCTION}

Restorative materials containing fluoride $(\mathrm{F})$ have been used with the objective to control the caries disease, since $\mathrm{F}$ has an important role in the remineralization process of the caries disorganized dental tissue (1-3). Previous studies have shown that teeth restored with silicate cement have significant lower incidence of secondary caries when compared to other materials, and this characteristic was attributed to the $\mathrm{F}$ release from this restorative material $(4,5)$. Considering the commercially available F-containing materials, glass ionomer cements (GICs) are those with the highest F release $(1,2,6-8)$.

GICs, originally introduced by Wilson and Kent (5) in the seventies, have been extensively studied, especially considering the $\mathrm{F}$ release. Most studies reported that the $\mathrm{F}$ release is higher in the first $24 \mathrm{~h}$ and is reduced to constant levels around 14 days $(3,6,9-$ 13). One of such studies (10) evaluated the F release, during 60 days, from 2 conventional GICs and 2 metalreinforced GICs, stored in deionized water and artificial saliva. Results showed that all the experimental materials released less $\mathrm{F}$ when stored in artificial saliva than in deionized water and that conventional GICs released more $\mathrm{F}$ than the metal-reinforced GICs in both types of media.

$F$ release in vivo and in vitro from 3 GICs (Vitrebond; 3M ESPE/ Ketac-Fil; 3M ESPE/ Chem Fil; De Trey) was also previously reported (14). To measure the F content in vivo, saliva was collected from children immediately after restoring teeth with GICs, and then after 3 weeks, 6 weeks and 1 year. In addition, 5 specimens of each GIC were fabricated and stored in deionized water for 11 weeks. At the 12th week, the specimens were immersed in toothpaste mixed with $2 \mathrm{~mL}$ of distilled water, and the $\mathrm{F}$ concentration was measured for more 5 weeks. The in vivo study showed that for all materials the lowest and highest $\mathrm{F}$ release rate was observed, respectively, immediately after the

Correspondence: Prof. Dr. Alvaro Della Bona, Faculdade de Odontologia, Universidade de Passo Fundo, 990001-970 Passo Fundo, RS, Brasil. Tel: +55-54-3316-8395. e-mail: dbona@upf.br 
restorative procedure and in the third week. In the in vitro study, for the 3 GICs, the highest F release was recorded during the first 3 weeks and after the toothpaste exposure, showing the $\mathrm{F}$ absorption-release ability of GIC restorations. The authors concluded that GIC can act as a slow $\mathrm{F}$ releasing material, both in vivo and in vitro (14).

F release from GIC restorations and its absorption by the enamel after demineralization/remineralization cycles have also been investigated (3). It was reported that GIC released significant amounts of F when stored in demineralization/remineralization solutions, releasing higher amount of $\mathrm{F}$ during the first days and stabilizing this process after 10 days. F incorporation to the enamel was greater in the superficial layers of this tissue.

GICs have been used as cements, restorative, filling and base agents, pit-and-fissure sealants and orthodontic cements $(12,15)$. Notwithstanding, these materials have been modified, mainly by the addition of resin components, to improve their mechanical properties, without an adequate evaluation of the $\mathrm{F}$ release phenomenon. Therefore, the objective of this study was to evaluate the $\mathrm{F}$ release from different GICs, testing the hypothesis that resin-modified GIC (RMGIC) presents a lower $\mathrm{F}$ release than conventional GIC, irrespective of the evaluation time.

\section{MATERIAL AND METHODS}

The in vitro $F$ release from 4 restorative materials from 3M ESPE (St. Paul, MN, USA) was assessed: Ketak Molar Easymix [KME - conventional GIC]; Rely-X luting 2 [RL2 - RMGIC]; Vitremer (VIT - RMGIC); Filtek Z250 [Z250 - composite resin, negative control].

F release evaluation was performed daily during 28 days, except for the first day when analyses were done every $6 \mathrm{~h}$. Nine disc-shaped specimens from each material were produced using a plastic matrix (Demetron disposable disk; Demetron Research Corp., Danbury, CT, USA) with $5 \mathrm{~mm}$ diameter, $3 \mathrm{~mm}$ thickness, and total surface area of $86.4 \mathrm{~mm}^{2}$. The isolated mold was positioned on a polyester strip sat on a glass slab. The materials were mixed on a glass slab under controlled room temperature $\left(23 \pm 2^{\circ} \mathrm{C}\right)$ and humidity, according to the manufacturer's instructions. The materials were carefully inserted in the mold to avoid the inclusion of air bubbles. After the first material layer had been inserted in the mold, the end of a little cord was placed into the mold that was completely filled with material. Another polyester strip and glass slab were positioned over the mold with digital pressure (approximately $5 \mathrm{~N}$ ) during $1 \mathrm{~min}$ to level up the specimen surface.

For the light-activated materials, a halogen bulb unit (Optilight Plus; Gnatus, Ribeirão Preto, SP, Brazil) with $420 \mathrm{~mW} / \mathrm{cm}^{2}$ light intensity was applied for 40 $\mathrm{s}$ from both sides of the specimens. The chemically activated materials were allowed to set for $20 \mathrm{~min}$ in room temperature before the matrix was removed.

Every specimen was attached to the lid of a plastic container by the specimen cord, which allows the specimen to be into $10 \mathrm{~mL}$ reverse osmosis water without touching the lateral and bottom walls of the plastic container. All containers with specimens were stored in an incubator at $37 \pm 1^{\circ} \mathrm{C}$ until the moment of the analyses.

The measurements were performed using the direct potentiometry method with a liquid membrane for selective F ion electrode. Two standard F solutions with concentrations of $5 \mathrm{mg} . \mathrm{L}^{-1}$ and $10 \mathrm{mg} . \mathrm{L}^{-1}$ were used to calibrate the measuring device (Orion 710 digital ionanalyzer; Orion Research Inc., Beverly, MA, USA) (16). Once calibrated, the analyzer performed the analyses of the specimen solution. For the analyses, the specimens were transferred to new containers with $10 \mathrm{~mL}$ of a total ionic strength adjustment buffer solution (TISAB) under constant agitation. After each reading, the electrode was washed with osmosis water.

$\mathrm{F}$ release data were analyzed statistically by two-way ANOVA and Tukey's test with a significance level of $5 \%$.

\section{RESULTS}

The mean $\mathrm{F}$ release values (in $\mathrm{mg} / \mathrm{L}$ or $\mathrm{ppm}$ ) of all tested materials after 6 h, 24 h, 7 days, 14 days and 28 days are presented in Table 1. All tested materials released significant amount of F, except for Z250.

RL2 released the greatest amount of F, followed by VIT and KME materials. Z250 material was used as a negative control and did not release $\mathrm{F}$.

Higher $F$ release values were observed in the first day, rapidly decreasing in the second and third days, and gradually decreasing in the following days until it reached a constant F-release level.

\section{DISCUSSION}

There are several studies on $\mathrm{F}$ release from 
restorative materials and most of them reported similar behavior as observed in this study $(13,14,16)$, meaning, high $\mathrm{F}$ release rates in the first $24 \mathrm{~h}$, following by a decrease in F-release until it reaches a plateau. As reported, this initial high $\mathrm{F}$ release rate contributes in vivo to eliminate microorganisms that are present during the cavity preparation and helps to strengthen the demineralized enamel and dentin (3). Glass ionomer cements have the ability to stop caries progression even under high cariogenic challenge conditions. The F released from the material is capable to interfere not only in the enamel demineralization, but also in the oral environment health, even in situations of high risk of caries $(16,17)$. The $F$ release decreases as ions begin to react with the matrix. The release drop, reaching constant levels, is ideal to reduce or even stop the development of new caries sites near the restoration, the released $\mathrm{F}$ also increases the F concentration in saliva (14).

In the present study, RL2 showed the highest rate of $F$ release during all 28 days. In addition, the $F$ release presented by the RMGICs (RL2 and VIT) was greater than that of the conventional GIC (KME).

Chan et al. (1) reported that GICs released significantly more $\mathrm{F}$ than a composite resin, in all periods and all time intervals examined. These observations are in agreement with the findings of another study (13) that also verified the ability of GICs to absorb F.

Direct comparisons between our results and those of previously published studies are difficult since previous studies reported on different commercial products with different compositions and different storage media and times. A study on the influence of storage media on F-release reported that the materials released more $\mathrm{F}$ in deionized water than in artificial saliva, due to the deionized water cations (10). Therefore, it is suggested that future studies use storage media that simulate the oral environment.

In the present study, the tested hypothesis could not be accepted, as RL2, a RMGIC, released the greatest amount of $\mathrm{F}$ in all periods $(\mathrm{p}<0.05)$, followed by VIT and KME. The control material, as expected, did not release $\mathrm{F}$. The $\mathrm{F}$ release behavior was similar for all the ionomer-based materials, with higher $\mathrm{F}$ release in the initial $24 \mathrm{~h}$ then decreasing to constant levels of F-release after 14 days.

\section{RESUMO}

O objetivo deste estudo foi avaliar, in vitro, a liberação de flúor (F) de 4 materiais restauradores (3M-ESPE): KME cimento de ionômero de vidro convencional (CIV) (Ketak Molar Easymix); RX2- GIC modificado por resina (RMGIC) (Rely-X luting 2); VIT-RMGIC (Vitremer); -resina composta Z250 (controle negativo) (Filtek Z250). As amostras foram confeccionadas de acordo com as instruções do fabricante e colocadas em $10 \mathrm{~mL} \mathrm{de}$ água destilada $37^{\circ} \mathrm{C}$ até as leituras, que foram feitas utilizando um eletrodo de íon seletivo de fluoreto de membrana líquida (Orion 710). A liberação de flúor foi avaliada a cada $6 \mathrm{~h}$ no primeiro dia e, diariamente durante 28 dias (d). Os resultados foram analisados estatisticamente usando ANOVA a dois critérios e teste de Tukey. A média e desvio padrão de liberação de $\mathrm{F}$, valores (em ppm) foram: KME: 6 h- 0,34 $\pm 0,04 ; 24$ h- 1,22 $\pm 0,30 ; 7$ d- 0,29 $\pm 0,09$; 14 d- $0,20 \pm 0,04 ; 28$ d- $0,16 \pm 0,01 ;$ RL2: 6 h- 2,46 $\pm 0,48 ; 24$ h- $12,33 \pm 2,93 ; 7$ d- $1,37 \pm 0,38 ; 14$ d- $0,80 \pm 0,13 ; 28$ d- $0,80 \pm$ 0,21 ; VIT: 6 h- $0,98 \pm 0,35 ; 24$ h- 4,35 $\pm 1,22 ; 7$ d- $0,66 \pm 0,23$; 14 d- $0,40 \pm 0,07 ; 28$ d- $0,39 \pm 0,08 ; Z 250: 6$ h- 0,029 $\pm 0,001$; 24 h- $0,024 \pm 0,009 ; 7$ d- $0,023 \pm 0,004 ; 14$ d- $0,025 \pm 0,001 ; 28$ d- $0,028 \pm 0,001$. Concluiu-se que RL2 liberou mais F do que os outros materiais em todos os períodos. A maior liberação de $\mathrm{F}$ ocorreu nas primeiras $24 \mathrm{~h}$.

Table 1. Mean fluoride release (mg/L or ppm) from the experimental groups after 6 h, 24 h, 7 days, 14 days and 28 days.

\begin{tabular}{|c|c|c|c|c|}
\hline Time & Rely-X luting 2 & Vitremer & Ketak Molar Easymix & $\mathrm{Z} 250$ \\
\hline $6 \mathrm{~h}$ & $2.46 \pm 0.48 \mathrm{Ab}$ & $0.98 \pm 0.35 \mathrm{Bb}$ & $0.34 \pm 0.04 \mathrm{Bb}$ & $0.029 \pm 0.001 \mathrm{Ca}$ \\
\hline $24 \mathrm{~h}$ & $12.33 \pm 2.93 \mathrm{Aa}$ & $4.35 \pm 1.22 \mathrm{Ba}$ & $1.22 \pm 0.30 \mathrm{Ca}$ & $0.024 \pm 0.009 \mathrm{Da}$ \\
\hline 7 days & $1.37 \pm 0.38 \mathrm{Abc}$ & $0.66 \pm 0.23 \mathrm{Bb}$ & $0.29 \pm 0.09 \mathrm{Bb}$ & $0.023 \pm 0.004 \mathrm{Ca}$ \\
\hline 14 days & $0.80 \pm 0.13 \mathrm{Abc}$ & $0.40 \pm 0.07 \mathrm{Bb}$ & $0.20 \pm 0.04 \mathrm{Cb}$ & $0.025 \pm 0.001 \mathrm{Da}$ \\
\hline 28 days & $0.80 \pm 0.21 \mathrm{Ac}$ & $0.39 \pm 0.08 \mathrm{Bb}$ & $0.16 \pm 0.01 \mathrm{Cb}$ & $0.028 \pm 0.001 \mathrm{Da}$ \\
\hline
\end{tabular}

*Mean values with different uppercase letters in same row are significantly different $(\mathrm{p}<0.05)$. Mean values with followed by different lowercase letters in the same column are significantly different $(\mathrm{p}<0.05)$. 


\section{REFERENCES}

1. Chan DW, Yang L, Wan W, Rizkalla AS. Fluoride release from dental cements and composites: A mechanistic study. Dent Mater 2006;22:366-373.

2. Gama-Teixeira A, Simionato MRL, Elian SN, Sobral MAP, Luz MAC. Streptococcus mutans-induced secondary caries adjacent to glass ionomer cement, composite resin and amalgam restorations in vitro. Braz Oral Res 2007;21:368-374.

3. Hicks J, Garcia-Godoy F, Donly K, Flaitz C. Fluoride-releasing restorative materials and secondary caries. J Calif Dent Assoc 2003;31:229-244.

4. Forsten L. Fluoride release of glass ionomers. J Esthet Restor Dent 1994;6:216-222.

5. Wilson $\mathrm{AD}, \mathrm{Kent} \mathrm{BE}$. A new translucent cement for dentistry, the glass ionomer cement. Brit Dent J 1972;132:133-135.

6. Itota T, Carrick TE, Yoshiyama M, Mccabe JF. Fluoride release and recharge in giomer, compomer and resin composite. Dent Mater 2004;20:789-795.

7. Santos RL, Pithon MM, Vaitsman DS, Araújo MTS, Souza MMG, Nojima MGC. Long-term fluoride release from resin-reinforced orthodontic cements following recharge with fluoride solution. Braz Dent J 2010;21:98-103.

8. Vermeersch G, Leloup G, Vreven J. Fluoride release from glassionomer cements, compomers and resin composites. J Oral Rehab 2001;28:26-32

9. Caves GR, Millet DT, Creanor SL, Foye RH, Gilmour WH. Fluoride release from orthodontic band cements - a comparison of two in vitro models. J Dent 2003;31:19-24.

10. El Mallakh BF, Sarkar NK. Fluoride release from glass-ionomer cements in de-ionized water and artificial saliva. Dent Mater 1990;6:118-122.

11. Forsten L. Fluoride release from a glass ionomer cement. Scand J Dent Res 1977;85:503-504.

12. Wiegand A, Buchalla W, Attin T. Review on fluoride-releasing restorative materials - fluoride release and uptake characteristics, antibacterial activity and influence on caries formation. Dent Mater 2007;23:343-362.

13. Weidlich P, Miranda LA, Maltz M, Samuel SMW. Fluoride release and uptake from glass ionomer cements and composite resins. Braz Dent J 2000;11:89-96.

14. Hatibivic-Kofman S, Koch G. Fluoride release from glass ionomer cement in vivo and in vitro. Swed Dent J 1991;15:253-258.

15. Rodrigues E, Delbem ACB, Pedrini D, Cavassan L. Enamel remineralization by fluoride-releasing materials: proposal of a pH-cycling model. Braz Dent J 2010;21:446-451.

116. Paschoal MAB, Gurgel CV, Rios D, Magalhães AC, Buzalaf MAR, Machado MAAM. Fluoride release profile of a nanofilled resinmodified glass ionomer cement. Braz Dent J 2011;22:275-279.

17. Passalini P, Fidalgo TKS, Caldeira EM, Gleiser R, Nojima MCG, Maia LC. Preventive effect of fluoridated ortodontic resins subjected to high cariogenic challenges. Braz Dent J 2010;21:211215 .

Received October 14, 2010 Accepted June 1, 2011 